\title{
Industrial infrastructure as an indicator of Russian GDP growth
}

\author{
V.V. Moiseev, Shukhov \\ Belgorod State Technological University, 46 \\ Kostyukova St., Belgorod, 308012 \\ Russia, \\ din_prof@mail.ru
}

\author{
E. A. Karelina \\ Moscow State University of Technology «STANKIN» \\ 1 Vadkovsky Lane, Moscow, 127055 \\ Russia \\ opferpriesterin@mail.ru
}

\author{
R.A.Khalturin, \\ Moscow State University of Medicine and Dentistry \\ 20 bld.1 Delegatskaya, Moscow \\ 127473, Russia \\ xalturin86@mail.ru
}

\author{
M.Yu. Karelina, \\ Moscow Automobile and Road State Technical University (MADI) \\ 64 Leningradsky Prospect \\ Moscow, 125319, Russia \\ karelinamu@mail.ru
}

\begin{abstract}
This article considers theoretical and practical aspects of the formation of industrial infrastructure. It specifies an important role of the state in building an efficient production infrastructure, the development of which will ensure the growth of the country's GDP.
\end{abstract}

In the process of formation and functioning of the production infrastructure elements, a specificity arises that generates an ambiguous relation associated with the participation of construction and operation of infrastructure facilities in the creation of GDP. The industrial infrastructure, as a superstructure of society, characterizes the deepest, most stable properties of the existing production relations in the country. A distinctive feature of the production infrastructure is associated not only with ensuring the continuity of the reproduction process by minimizing production costs and increasing the competitiveness of the final product, but also with the possibility of attracting extra-budgetary investment sources for implementing large infrastructure projects (roads, bridges, engineering communications, etc.).

The issue of increasing investment into productive infrastructure is an acute problem. This is significant not only for the infrastructure itself, but also for the development of social production as a whole. Large-scale investments in industrial infrastructure can become a multiplier of the country's economic growth, which will allow achieving a level of economic and social development corresponding to the status of Russia as the "leading world power of the 21 st century".

Keywords-industrial infrastructure; GDP; transport; state; economic growth.

\section{INTRODUCTION}

Considering the current situation in Russia, when GDP growth in 2017 amounted to $1.5 \%$ [16], one of the decisions to stimulate the country's economy remains a significant increase in investments in the production infrastructure. Without the development of industrial infrastructure, the implementation of large investment projects is delayed, attraction of extrabudgetary funds and foreign investment is slowing down, which significantly limits the country's social and economic growth. Such a tool to stimulate the economy and business activity is widely used throughout the world. According to the consulting company Moody's Economy, every dollar invested in infrastructure projects will have a multiplier effect of \$ 1.59 [6]. The development of road infrastructure was one of the priorities that allowed the US in 1929-1933 overcome the economic crisis.

In the face of Western sanctions, a sharp drop in prices for oil and other commodities, Russia has found itself in a difficult political and economic situation. President Putin, addressing the Federal Assembly on March 1, 2018, paid special attention to the importance of the economic development of our country, pointing out not only the shortcomings that existed, but also defining the main directions of work for the next six-year term in this field. V. Putin offered to "support high-tech companies in every possible way, build a favorable environment for startups, for the rapid introduction of new developments into production," and to create a convenient infrastructure, comfortable tax regimes, and protect intellectual property." These and other measures, according to the president, will help accelerate the processes of re-industrialization in our country as well as stimulate economic growth.

To ensure sustainable economic growth, the president proposed to increase investments to 25 percent of GDP and direct them, first of all, to modernization and technological reequipment of industries, renewal of industry. "We need to ensure the highest dynamics here, to reach a level where on average every second enterprise carries out technological changes during the year," the head of state said. "That's when the economy and industry will be renewed [1].

To fulfill these and other tasks which the head of state set out in a message to the Federal Assembly in March 2018 to increase the pace of Russia's socioeconomic development joint efforts of the authorities and business will be required.

\section{PROBLEM STATEMENT}

It should be noted that the problem of infrastructure is extremely complex and multifaceted. Theoretically and methodologically, the infrastructure has not been sufficiently studied, there is no unity of views on the place and role of infrastructure in the reproduction process, its essential content, classification of infrastructure industries, interconnections at 
the micro, meso and macro levels. As a rule, at the macro level, the production infrastructure is allocated (associated with the social division of labor and the complication of production links), the social one (providing the vital activity of the population), the institutional one (associated with governance institutions), as well as the environmental one (preservation of the natural habitat) and others.

Based on the economic essence of infrastructure, it is also possible to determine its main functions related to the ongoing social and economic processes [6]. At the same time, it is necessary to take into account the peculiarities of the functioning of the infrastructure, determined by its nature in providing services, in ensuring the sustainability of production and in saving costs for the creation of infrastructure facilities due to the integration effect on inter-branch relations [9]. The available data show an increase in the costs of market research, the search for counterparties, the execution of contracts, transportation, warehousing and storage of goods.

Providing services to ensure the sustainability of the reproductive process at all its stages and organization of spatial relations is the most important function of the infrastructure. It concerns economic complexes, regional and municipal production and social structures. At the same time, the unity of commodity, monetary and information flows must be ensured, which would create common conditions for maintaining the sustainability of the reproduction process in the necessary proportions and scales.

The generally accepted classification of infrastructure at the macro level implies its division into production and nonproduction. The production infrastructure, as a symbiosis of industries that serve material production, includes transportation, communications, logistics and other industries and fields. Non-productive, and, in fact, social and household infrastructure ensures the reproduction of labor, general conditions of life: education, health, tourism, etc. [14]. However, this division does not reflect the real development of new technologies, communications and inter-branch relations. Therefore, it is advisable to distinguish not only the production and social infrastructure but also other ones: institutional, environmental, etc.

In modern conditions, innovative and information infrastructures are of significant importance. Innovative infrastructure includes both technology parks, incubators, technology promotion centers, etc., as well as financial institutions or development institutions [5]. And in this regard, the innovative infrastructure is an integral part of the overall organizational and economic infrastructure system, which has its own specifics. Innovative infrastructure is based on generally accepted production networks and includes various types of institutions: technological, financial, development institutions.

Due to the weak interchangeability of the production infrastructure, specific features of the functioning of the infrastructure sectors at the federal, regional and municipal levels appear. The deficit of engineering networks, roads and other infrastructure areas in some regions cannot be compensated by their excess in other regions. The specifics of the formation of infrastructure branches are connected with the existing unified scheme for the development and deployment of the country's productive capacity. Regions where industry has been developing rapidly throughout the history have appropriate allocation of industrial infrastructure fields. Industrial centers concentrate the population, which means further development of non-productive infrastructure, transport, road construction, trade, health, etc., which, ultimately, is determined by investment opportunities [13].

In the process of formation and functioning of the elements of the production infrastructure, a specificity arises that generates an ambiguous attitude associated with the participation of construction and operation of infrastructure facilities in the formation of the GDP. Thus, the process of building a road is, in principle, the creation of a newly created value in the construction of an infrastructure facility that ensures the growth of the newly created value, and the process of road maintenance creates only conditions for the production process. It means certain activities to provide services in order to ensure the continuity of the reproduction process (in fields associated with road maintenance), but the infrastructure sector does not create a tangible product.

Transport is one of the most important branches of the national economy, providing the basic conditions for the life of society. It plays the role of a cementing factor in various spheres of the economy, ensuring the production and circulation of industrial and agricultural products, the needs of capital construction and those of the population for transportation.

Transport is a rather complex system, within which 6 types of transport (air water, rail, road, space, pipeline) and road facilities operate. Each of them has got significant features that could not but affect the organization of managing the entire system. The system of public transport management is one of the subsystems of social management, it has a certain internal organization, functions, properties and connection with other systems. Transportation infrastructure assets-airports, seaports, railways, roads - constitute the backbone of any economy. Each dollar plowed into such assets boosts gross domestic product (GDP) and has a multiplier effect on job creation. Owners of such infrastructure assets therefore play a vital role in driving sustained economic growth. However, they face multiple challenges that limit their assets' power to drive GDP and job growth. To surmount these challenges, owners must first understand them and then build new capabilities for overcoming them.

State management of transport can be defined as a purposeful, systematic, continuous activity of public authorities aimed at creating and ensuring the timeliness and quality of sea, river, air, rail and road transport. This activity's form is manifested in the executive-administrative form and its content is associated with management of economic entities [3].

It should be noted that all significant historical changes in the development of Russia are associated with various milestones in the development of transport: water, rail, road, pipeline. However, the main function of the transport system is to ensure the unity of federal and regional markets, the formation of a single economic space, and the provision of internal migration of the population. Without a well-developed transport infrastructure, there appear difficulties in both 
ensuring structural adjustment of the economy and enhancing economic growth. Transport can play an important role in promoting growth, diversification and regional convergence. However, with insufficient investment and incomplete structural reforms, Russia faces very large challenges in modernising its large transport system. Urban transport problems are intensifying, because of weak policy coordination and inadequate traffic management. Promoting competition in the transport sector is essential, in particular by effectively opening the railway freight market to independent operators. Russia's transportation system is extensive, but is in a state of general decay. Maintenance, modernization, and expansion are required for Russia's infrastructure, much of which operates beyond capacity.

Due to natural and geographical features and economic opportunities in various countries the structure of transportation is differently formed. Specific weight of certain modes of transport in total turnover of goods can be seen in the table given below.

TABLE I. SPECIFIC WEIGHT OF CERTAIN MODES OF TRANSPORT IN TOTAL TURNOVER OF GOODS $(\%)$

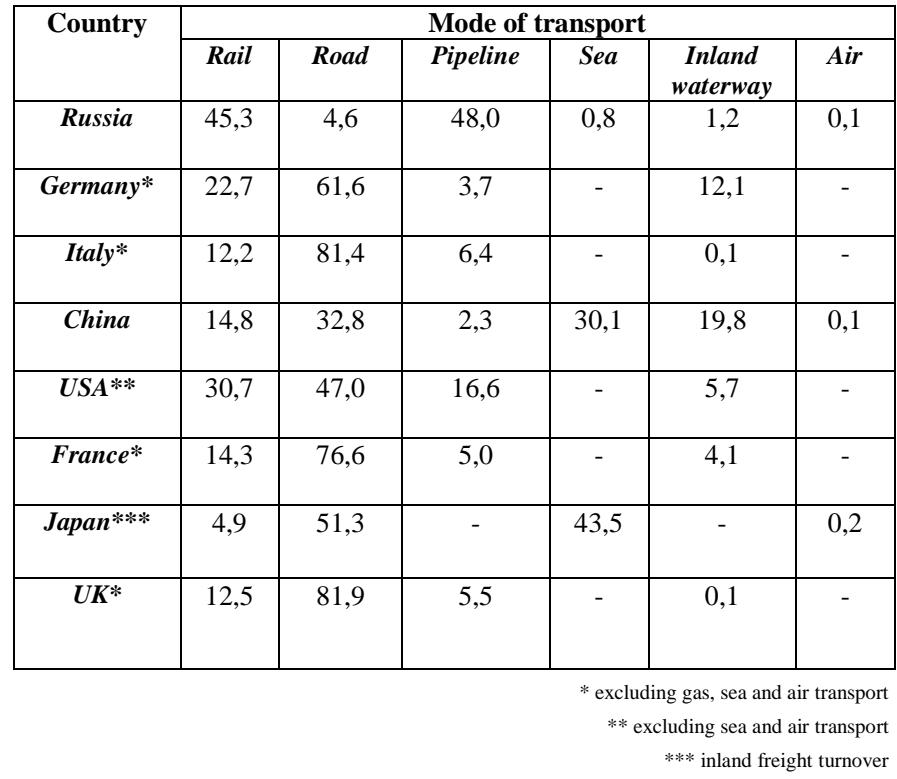

As it can be seen from Table 1, in developed countries of Western Europe, which are characterized by a relatively small area and distinguished by developed automobile routes, motor transport has a much larger share in the turnover of goods. The density of highways is $1932.1 \mathrm{~km}$ of roads per $1000 \mathrm{~km}^{2}$ of territory, while in Russia, for comparison, this figure amounts only to $86.5 \mathrm{~km}$. Naturally, with such a density of hard-surfaced roads in France, $76.6 \%$ of cargo turnover is carried out by cars.

In general, in countries with a small territory, road transport predominates in cargo traffic. As a rule, in countries with significant territories, the share of railway transport increases (USA - 30.7\%, Russia - 45.3\%). The Russian railways are ranked second longest globally, behind the railways of the United States. The volume of freight hauled is third behind the United States and China.
Road transport in Russia occupies a significant proportion in the transportation of passengers and goods, and the further development of road transport is largely determined by the state of the road network, and in particular, roads. Automobile roads belong to those links of a transport network, without the necessary quantity and quality of which it is impossible to operate (with rare exceptions) any branch of the national economy. The availability of roads has a complex impact on economic development by reducing costs; it also influences social stability, both in individual regions and in the country as a whole.

The specificity of transport is the non-material nature of the output produced, so the main task of transport is the provision of services for the transportation of goods and passengers while ensuring a continuous process of their movement [11]. In the market conditions for the high-quality implementation of the transportation process on the road network, the availability of roads is not enough, and a highly developed road infrastructure is needed.

The condition for a formation of the road network is demand and supply. The supply forms demand through the assortment of goods produced (and the price level) [10]. In turn, demand, as a public need, determines the volume and structure of the commodity supply. The throughputs of road networks are mainly responsible for the formation of supply, and demand forms the flow of commodity supplies and all this occurs in the infrastructure transport market. This market is connected with the presence of a network of highways, car companies and consignors, well-developed logistics, and an established system of road infrastructure maintenance. The lack of modern transport infrastructure in Russia affects the national security of the country, increases the costs of enterprises, exacerbates social problems. Deficiency in transport and communications infrastructure is one of several supply chain barriers that act as obstacles for speeding up economic growth. Increased operational costs, increased demands on investment and working capital, and cargo delivery delays are often found to be the consequences of inadequate infrastructure, discouraging individual company trade growth and participation which leads to certain problems hindering the overall economic development of a country.

TABLE II. TRENDS IN CHANGES OF INFRASTRUCTURE ELEMENTS MAINTAINING THE ROAD NETWORK (END OF THE YEAR; THOUSANDS OF UNITS)

\begin{tabular}{|l|c|c|c|c|}
\hline $\begin{array}{c}\text { Elements of } \\
\text { infrastructure }\end{array}$ & $\mathbf{2 0 0 5}$ & $\mathbf{2 0 1 1}$ & $\mathbf{2 0 1 5}$ & $\begin{array}{c}\mathbf{2 0 1 5} \text { as } \\
\mathbf{2} \text { of } \\
\mathbf{2 0 0 5}\end{array}$ \\
\hline Parking areas & 3,2 & 4,1 & 4,6 & 143,8 \\
\hline Rest areas with overpass & 0,6 & 0,6 & 0,5 & 83,3 \\
\hline Washing points & 0,2 & 0,3 & 0,3 & 150,0 \\
\hline Retail outlets & 4,7 & 4,4 & 4,4 & 93,6 \\
\hline Catering facilities & 4,0 & 4,2 & 3,9 & 98,0 \\
\hline Motels, camping sites & 0,5 & 0,6 & 0,7 & 140,0 \\
\hline Petrol stations & 4,4 & 4,9 & 4,8 & 113,6 \\
\hline Maintenance stations & 1,1 & 1,2 & 1,1 & 109,1 \\
\hline First-aid posts & 0,5 & 0,5 & 0,4 & 80,0 \\
\hline Points of contact & 0,9 & 1,1 & 1,2 & 133,3 \\
\hline
\end{tabular}

Referring to the elements of the infrastructure shown in Table 2, we note that for the past few years the road 
infrastructure has not been given adequate attention in the Russian Federation except for motels, washing stations and gas stations. The Russian road infrastructure does not meet the western standards of road network construction. There are not enough maintenance stations on the country's roads, roadside food and trade points are usually placed chaotically, without taking into account the needs of the traffic participants. In Europe, the absence of at least one mandatory element of the road infrastructure automatically means a refusal to put the facility into operation. The major part of these facilities is small businesses, which form a significant part of the country's GDP.

Characteristics of technical and operational parameters of highways, other man-made structures, road maintenance facilities determine the quality of road infrastructure. Besides the artificial constructions intended for movement of vehicles, a developed road infrastructure means presence of objects of road service. The Russian road network is poorly provided with road service objects and could hardly catch up with road networks of foreign countries, and this reduces the speed of cargo delivery and, hence, reduces the competitiveness of highways.

It should be noted that the Government of the Russian Federation is taking significant measures to solve the transport problems of Russia and, in particular, the problems of highways. Their construction is carried out in accordance with the Federal Program "Development of the transport system of Russia (2010-2020), and, in particular, with the subprogram" Automobile roads [2]. The term of the existing program "Modernization of the Transport System of Russia (20022010)" has been prolonged for the period until 2020, and its name has been changed to "Development of the Transport System of Russia (2010-2020)". The need for maintenance, repair, and expansion of transportation infrastructure in the future will require consistent funding sources. Whether current funding levels are adequate for addressing these needs is a question that must be answered.

\section{RESEARCH QUESTIONS}

1. The identification of the role of industrial infrastructure in ensuring a multiplicative impact on social and economic processes.

2. Substantiation of conceptual approaches to the formation of a united transport space of the country.

\section{PURPOSE OF THE STUDY}

The purpose of this study is to develop recommendations for improving the country's industrial infrastructure.

\section{RESEARCH METHODS}

In the article the authors used such research methods as comparative and institutional ones, and also the method of systematic approach.

\section{FINDINGS}

The given research of industrial infrastructure allows us to determine the crucial findings of this study.

Firstly, in the field of transport management and regulation the state needs to focus on such a strategic goal as promoting economic growth and improving the welfare of the country's population through access to safe and quality transport services and turning Russia's geographical features into its competitive advantage.

To achieve this strategic goal, it is necessary to reach the following objectives.

1. Development of an efficiently functioning transport infrastructure, ensuring an accelerated traffic flow and reducing transport costs.

2. Increasing the availability of transport services for all segments of the population in different regions of the country.

3. Realization of the transit potential of the country.

4. Improving the safety and stability of the transport system.

\section{Improving the investment climate.}

Secondly, to solve the infrastructure problems in modern Russia, it is important to determine the degree of the country's readiness for an innovative breakthrough, the level of housing provision and transport infrastructure, including roads, air transportation as well as the competitiveness of rail transport, but it is investment and innovative provision of the entire complex of infrastructure facilities that is of principal importance. Russia has a huge transport potential in the development of high-speed communication, possibly connecting Japan, China and the Far East into a single transport hub, the economic benefits from this project are enormous, but the situation with transport infrastructure in Russia deprives the state of such prospects.

Thirdly, in the budget of the Russian state, which owns the major part of the industrial and social infrastructure, there is not enough money to modernize obsolete funds. The lack of public funds for financing the infrastructure can be compensated by involving the business in financing the production infrastructure on the basis of partnership between the state and the private sector. The interaction of government and business becomes a condition for the formation of an effective economic policy, as well as for increasing investment and innovation activity in the country as a whole and its regions and also with using adequate regional strategies, this kind of interaction will allow to increase GDP growth rates, increase the efficiency of the budget sector of the economy, and reduce costs when implementing infrastructure projects. The partnership between the state and business represents the institutional and organizational process between the state and private companies, banks, international financial organizations for the implementation of socially significant projects, where the forms of this interaction may differ depending on national peculiarities and circumstances.

Moreover, encouraging partnership, the state activates the management methods, shifting the functions of property management to the private sector, which in turn, by means of state assets and guarantees, uses its organizational experience, know-how, carries out investments, minimizes the risks of entrepreneurial activity. The partnership represents the mechanism of harmonious and effective development of the economy, guaranteeing the protection of people's interests, 
resolving the contradictions between servicing public interests and ensuring profit in the dynamics of development, forming a culture of interaction between government and business, positively affecting social and economic relations in Russia. To increase investments in production infrastructure is an urgent problem. This is significant not only for the infrastructure itself, but also for the development of social production as a whole. Large-scale investment in production infrastructure can become a multiplier of the country's economic growth.

\section{CONCLUSION}

In conclusion, the authors claim that no matter how well the production infrastructure was built, it might be extremely difficult to achieve success without well-trained personnel. This has been confirmed by Lee Kuan Yew, the author of the Singapore miracle. His approach in forming the government was to place the most capable, not the most devoted people at the head of the most important ministries. "This is an equal opportunity for all. It is a system of advancement according to merit, in which the best place is occupied by the most worthy person"[7]. But the state model used in this or that country is generally specific, and therefore it is difficult to reproduce it in the same way in another country. "However, in each state model, experience emerges during the management process, careful study of which enables other countries to learn useful lessons, which will help avoid mistakes in the process of forming its own management model" [4].

The authors of the article express the hope that President Vladimir Putin will use his new six-year term as head of state to change the relationship of power to business for the better, to reduce corruption and raiding, to reduce the outflow of capital to offshore so that by joint efforts of the authorities and business, creatively using international experience, to bring Russia to a number of prosperous countries in the world.

\section{References}

[1] The President's Address to the Federal Assembly, 2018. - Retrieved from: http://kremlin.ru/events/ president/news/56957.

[2] "Resolution of the Government of the Russian Federation", No. 848 of 05.12.2001 (as amended on May 15, 2014), "On the Federal Target Program" Development of the Transport System of Russia (20102020)"

[3] S.N. Bratanovsky, O.G. Ostapets, "The legal organization of management of a transport complex of the Russian Federation", Moscow: Direct Media, 2012.

[4] V.D.Gribov, Management: tutorial, Moscow: KNORUS, 2008, 280 p.

[5] A.G.Zeldner, "National model of social and market development of Russia on the basis of a mixed economy and the mechanism of publicprivate partnership", Moscow, Ankil, 2017, 84 p.

[6] A.G. Zeldner, «The state in the system of providing sustainable economic development», Bulletin of the Institute of Economics by Russian Academy of Sciences, vol. 2, p. 66-77, 2012

[7] V. Kondratiev, «Infrastructure and economic growth», World Economy and International Relations, vol. № 11, p. 18-22, 2011.

[8] Yu. Lee Kuan, "Singapore's history: 1965-2000. from the third world - to the first", Moscow: MGIMO-University, 2010, 656 pp.

[9] K. Marx, F. Engels, Wage Labour and Capital, Moscow: Politizdat, 1957. - Institute of Marxism-Leninism at Central Committee of the Communist Party of the Soviet Union. Collected works, edition 2, book 6, p. 441.

[10] G. Mintsberg, J.B. Quinn, S. Goshal «Strategic process: translated from English», Saint-Petersburg: Piter, 2001, p. 74-136.

[11] V.S. Osipov, «Competition, based on the joint creation of value in the agricultural machinery industry», Perspectives of science, vol. 10 (49), 2013, pp. 210-213.

[12] V.S. Osipov, «Institutional field of interacting economic entities», Economics and entrepreneurship, vol. 12-4, 2013, p. 405-409.

[13] S.A. Popov, Strategic Management: an actual course, Moscow: Urait Publishing House, 2016, 463 p.

[14] "Transport and communications in Russia", 2012: Stat. Sat, Rosstat, Moscow, 2012. 304 p.

[15] "Transport and communications in Russia", 2016: Stat. Sat, Rosstat, Moscow, 2016. $112 \mathrm{p}$.

[16] Towards the elections: GDP does not impress. URL:https://www.gazeta.ru/business/2018/02/01/11633353.shtml?up dated (1.02.2018) 